\title{
A NEUROMARKETING AKTUÁLIS HELYZETE ÉS A MINTAELEMSZÁMRA VONATKOZÓ KIHÍVÁSAI, KÜLÖNÖS TEKINTETTEL A SZEMKAMERÁS MÉRÉSEKRE
} THE CURRENT STATE OF NEUROMARKETING AND ITS CHALLENGES
IN SAMPLE SIZE, WITH A PARTICULAR FOCUS ON EYE TRACKING
MEASUREMENTS

A neuromarketing-vizsgálatok sajátossága, hogy kvalitatív és kvantitatív eljárások közé is besorolják a szakirodalomban. Ennek oka leginkább az, hogy a résztvevők száma inkább a kvalitatív mintanagyságok méretéhez igazodik, miközben a mérési pontokból származó adatok mennyisége lehetővé teszi a kvantitatív elemzéseket. Jelen összefoglaló a műszeres megfigyelések egy típusának, a szemkamerás vizsgálatok módszertani értékelésére fókuszál, különös tekintettel a megfelelő mintanagyság meghatározására. A probléma abból adódik, hogy ezek a vizsgálatok a szem mozgásának detektálásával a tudatalatti reakciók mérésére alapulnak, ezzel együtt nagy előnyének tekintik, hogy az agyi mechanizmus hasonlóságai révén alacsony résztvevői elemszám mellett a társadalomtudományi kutatásokban elvárt, magas megbízhatóságú statisztikai eredményeket szolgáltat az adott célcsoportra nézve. Ezért itt a szerző összefoglalja, hogy milyen mintanagyságok javasoltak a szemkamerás mérések esetében akkor, ha a megbízhatóság fontos szempont.

Kulcsszavak: neuromarketing, műszeres megfigyelések, szemkamera, mintanagyság, megbízhatóság

One of the neuromarketing particularities is that it can be classified as qualitative and quantitative research technique since the number of participants is more closely related to qualitative sample sizes, however, the huge amount of measured data allow us to analyze them quantitatively. This summary focuses on the evaluation of a special type of observation, namely eye tracking methodology, particularly on to define the appropriate sample size. This method is based on the detection of eye movements to measure unconscious reactions, along with its great advantage that is it can provide reliable statistical results with a low sample size due to the similarity of the brain mechanism. These results can be interpreted in connection with the behavior of a specific target group. The author attempts to summarize the literature recommendations about the appropriate sample size in eye tracking projects if reliability is a relevant aspect.

Keywords: neuromarketing, observational methods, eye tracking, sample size, reliability

\section{Finanszírozás/Funding:}

A szerző a tanulmány elkészítésével összefüggésben nem részesült pályázati vagy intézményi támogatásban.

The author did not receive any grant or institutional support in relation with the preparation of the study.

\section{Szerző/Author:}

Lázár Erika, PhD-hallgató, Pécsi Tudományegyetem, (lazar.erika@ktk.pte.hu)

dr. Szűcs Krisztián, egyetemi docens, Pécsi Tudományegyetem, (szucsk@ktk.pte.hu)

A cikk beérkezett: 2018. 07. 19-én, javítva: 2019. 04. 18-án, elfogadva: 2020. 02. 07-én.

This article was received: 19. 07. 2018., revised: 18. 04. 2019, accepted: 07. 02. 2020.

A marketing mint diszciplína és mint vállalati gyakorlat is számos új kihívással szembesült az elmúlt évek során, melyben szükségszerü a kutatási eszközök és az azok által hozott eredmények értékelése és újragondolása. A marketingszakma gyors változása mellett az is látszik, hogy új típusú adatok jelennek meg, melyekhez kapcsolódva új elemzési módszerek is születnek, ezzel biztosítva a korábbiaktól eltérő szemléletű insight-okat, közelítéseket. A marketingkutatások végső célja pedig, hogy olyan eredmények szülessenek, melyek hatékonyan építhetök be a vállalat döntéshozatali folyamatába, ezzel is támogatva az állandó növekedési kényszert, a legtöbb esetben jelentősen telített piaci szituációkban. Ezzel párhuzamosan kijelenthető, hogy a hagyományos módszerek már kevésbé 
hatékonyak, nem képesek az újszerü közelítések iránti igényt kielégíteni (Research Priorities, 2016).

Ebben a megváltozott környezetben négy meghatározó kihívással kell megküzdenie a marketingkutatóknak. Az egyik legnagyobb kihívást a kutatók számára az új technológiák és innovatív módszerek térnyerése és azok megértése okozza. Az innovációs kényszerhelyzet mellett a legnagyobb kérdés az, hogy miképpen lehet ezeket a technológiákat hatékonyan integrálni a korábbi portfólióba úgy, hogy közben az ügyféloldali elvárásokat továbbra is teljesíteni tudják annak érdekében, hogy a vállalkozás versenyképessége hosszabb távon is fennmaradjon. Ezzel egyidőben pedig olyan kutatócégek jelennek meg, melyek az új technológiákra specializálódnak és a piaci versenyt kiterjesztik egészen újszerü területekre. Ezek a vállalatok szolgáltatásaikkal és erős márkanevükkel komoly tényezőként jelennek meg a piacon úgy is, mint tanácsadó cégek (McKinsey, IBM, Deloitte), DIY kérdőívek (Survey Monkey) és Big-Data előállító vállalatok (Google, Facebook). A marketingkutatók számára életbevágó kérdéssé vált, hogy miként jelenítsék meg és fejlesszék értékteremtő és -közvetítő szolgáltatásaikat. A kutatócégek számára létkérdés, hogy ne csupán adatszolgáltatóként, hanem partnerként müködjenek együtt az ügyfelekkel a kutatási probléma mélyebb megismerése és komplex megválaszolása érdekében. Az előzőekben vázolt kihívások következményei számosak, ezek közül jelen tanulmányban részletesebben foglalkozunk a mintavétellel és az adatminőséggel kapcsolatos nehézségekkel, amelyek a neuromarketing, azon belül pedig a szemkamerás vizsgálatok kapcsán jelentkeznek. Ennek hátterében az alacsony válaszadási hajlandóság és a válaszadói torzítás miatt létrejövő rossz minőségű adatok kezelése áll (GRIT Report, 2018).

A kialakult helyzet nem újkeletü és sajnos nem is várható ezen a területen pozitív változás (GRIT Report, 2018), hiszen az iparági szereplők a hagyományos megkérdezésből származó adatok romló minőségére számítanak a jövőben is, mivel

- egyre inkább csökken az online válaszadási hajlandóság is, melyben nagy szerepet játszanak adatbiztonsággal kapcsolatos félelmek,

- a mobileszközök sokkal nagyobb kötődést képesek kialakítani, ami szükségessé teszi a megkérdezések formájának újra gondolását,

- általánossá válnak a tranzakciókhoz kapcsolódó adatgyüjtések, mivel a cégek számára egyre fontosabb, hogy azonnali visszajelzést kapjanak ügyfeleiktől, ezért nehéz kitünni és rábírni őket a hagyományos megkérdezésekre, nagyon úgy tünik, hogy a megokosodott fogyasztók (Töröcsik, 2011) túlterheltté válnak a feedback-kényszer miatt,

- a minőségi adatgyüjtésre törekvés gyakran hosszú és fárasztó kérdőíveket szül, ami bár számos kérdésre kitér, mégsem képes a megfelelő elemszámú minta elérésére, ami szintén az adatminőség kárára megy (Szücs, 2016).

\section{Egy lehetséges válasz a kialakult helyzetre: a neuromarketing}

Ebben a gyors ütemben változó kommunikációs és technológiai környezetben komoly kihívást jelent a marketingkutatással foglalkozó szakemberek számára a megbízható és releváns információk összegyűjtése a hagyományos módszerek eszköztárának segítségével, hiszen a fogyasztók válaszadási és részvételi hajlandósága folyamatosan csökken (Szücs, 2014). Ezzel párhuzamosan a marketingkutatási eszközök fejlődését a fogyasztói attitüdök, motivációk és érzések minél mélyebb és részletesebb megismerésének vágya mozgatja. A technológiai adottságok előnyeit kihasználva a neuromarketing - innovatív interdiszciplináris területként - a müszeres mérések használatára hagyatkozik, amikor a különböző ingeranyagokra adott kognitív válaszokat vizsgálja (Bercea, 2013). A különböző biológiai funkciók rögzítésére alkalmas eszközök gyors fejlödése és elterjedése teszi lehetővé ezeknek az innovatív eszközöknek az egyre szélesebb körben történő használatát, melyhez az általunk fókuszba helyezett, szemkamerás kutatások is sorolhatók.

Ariely és Berns (2010) az újszerü kutatási eszközök népszerüségének növekedését két szempontból közelíti meg. Egyrészt indokolja a neuromarketing-módszerek költségének folyamatos csökkenése, miközben egy, a hagyományos piackutatási módszerhez képest gyorsabb megoldásról van szó. Másrészt pedig olyan információt szolgáltat a marketingszakemberek számára, melyek nem elérhetők a konvencionális kutatási technikákkal, hiszen a tudatos válaszokon túlmenően a tudatalatti reakciók gyökereire helyezi a hangsúlyt, amikor az érzelemalapú, korlátozottan racionális választásokat vizsgálja (Varga, 2016).

Tanulmányunkban kutatás-módszertani közelítésből indítva elsőként a neuromarketing-módszerek helyét mutatjuk be, majd figyelmünket a szemkamerás mérések felé irányítjuk, választ keresve arra, hogy miként tudnak ezek a kutatási megoldások megbízható eredményeket biztosítani nagy elemszámú minta felvétele nélkül. Ehhez pedig az elmúlt években az ebben a témakörben megjelent elemzések és összefoglalók különböző tapasztalatait, felvetéseit tekintjük át.

A tudományterület által leggyakrabban használt megoldások közé sorolható az agyi aktivitást mérő fMRI (Functional Magnetic Resonance Imaging), PET (Positron emission tomography), EEG (Electroencephalography), MEG (Magnetoencephalography), TMS (Transcranial magnetic stimulation), vagy a szem mozgását detektáló szemkamera (Eye Tracking), melyeket komplexebb kutatásokban kiegészítő eszközként alkalmaznak (Bercea, 2013).

Bár az elemzésünk középpontjában a szemkamerás kutatások állnak, úgy gondoljuk, hogy az eszköz egyediségének kiemelése érdekében fontos, hogy röviden áttekintsük a leginkább elterjedt megoldásokat. Az fMRI a vér vastartalmát kihasználva mágneses mező és rádióhullámok kombinációjával teszi lehetővé az agy strukturális jellemzőinek és folyamatainak rögzítését. Ez a kísérleti 
eljárás alkalmas a különböző ingerek által kiváltott agyi aktivitások és viselkedési mintázatok mérésére. Mivel az adatok rögzítése és feldolgozása is speciális eszközök és szoftverek segítségével történik, így a módszer igen költséges. Ahogyan a pozitronemissziós tomográfia is, mely az fMRI-hez hasonlóan háromdimenziós képet készít az adott szervről vagy szövetről a pozitronok sugárzása segítségével. A neuromarketing-kutatások által egyik leginkább használt megoldás az elektroenkefalográf (EEG), mely az agyhullámok rögzítésére épül, melyek amplitúdója megfelel bizonyos mentális állapotoknak, így például az ébrenlét (béta hullámok), a relaxáció (alfa hullámok), a nyugalom (theta hullámok) és az alvás (delta hullámok) detektálható. Mivel az adatfelvétel a résztvevők fejére rögzített elektródákon keresztül történik, így az EEG egy hordozható kutatási eszköz tud lenni. Ehhez képest a magnetoenkefalográfia (MEG) az agyi aktivitásokat a bőr szintjén rögzíti. Az EEG-hez képest ebben az esetben a mágneses mezőt nem befolyásolja a szövetek típusa, azonban a kísérlet megvalósításához a föld mágneses mezejétől mentesített helyiségre van szükség. A transzkraniális mágneses stimuláció egy speciális mágneses mező kibocsátásával lehetővé teszi a mélyebben elhelyezkedő agyszövetek vizsgálatát is. Mindamellett, hogy az előbbieknél költséghatékonyabb megoldásról van szó, az eszköz ok-okozati összefüggések feltárására is alkalmas a mélyebb és összetettebb vizsgálódás révén, így a pszichológiai és marketingkutatások területén is nagyobb sikerrel alkalmazható.

A fogyasztói viselkedés, a vásárlási döntéshozatal folyamatának és a marketingkommunikációs anyagok hatékonyságának mérésére egyre gyakrabban alkalmaznak innovatív kutatási módszereket. A neuromarketing-eszközök segítségével lehetőség nyílik a tudatalatti motivációk, preferenciák és érzések megismerésére is, amelyeket kiegészítve a „szokásos” megkérdezési technikákkal, a tudatosult impulzusokat, a döntést befolyásoló tényezőket is vizsgálhatjuk. Nagy előnye tehát ezeknek a vizsgálatoknak, hogy korábban nem vizsgálható aspektusait tudjuk mérni a döntési folyamatoknak. Itt fontos kiemelni, hogy az eredmények jellemzően nem teljes populációra, hanem pontosan meghatározott demográfiai és viselkedési jellemzők alapján definiált célsokaságra vonatkoznak, így a kutatás alapsokaságát a legtöbb esetben egy jól körül határolható célcsoport jelenti.

A technológiai háttér gyors ütemű fejlődése révén a neuromarketing többet kínál a hagyományos kvantitatív és kvalitatív kutatási módszereknél azáltal, hogy közvetlenül méri a marketingingerek által kiváltott biológiai reakciókat (Simon, 2016). Ez a tudományterület a fogyasztói idegtudomány, a neuro-közgazdaságtan és a pszichológia egy olyan találkozása, amely a marketing szempontjából releváns problémákat vizsgál és eddig hiányzó elemként kapcsolja össze a fogyasztó gondolkodását a cselekedeteivel (Hubert, 2010).

Ennek létjogosultságát az a jelenség is bizonyítja, amit Herbert Simon már az ötvenes évek közepén korlátozott racionalitás elméleteként fogalmazott meg, melyben arra hívja fel a figyelmet, hogy az emberi kapacitások alapve- tően nem elegendők az objektív racionalitás alapján történő döntéshozatalra (Simon, Hajnal, Kindler, Kiss, \& Csontos, 1987). Pszichológiai szempontból a fogyasztói viselkedést olyan alapvető folyamatok határozzák meg, mint a motiváció, az észlelés, a tanulás és az emlékezet (Loken, 2006), melyek alapját azok a biológiai és pszichés eredetű igények képezik, melyek intenzitásukból fakadóan cselekvésre késztetik az egyént. Ezt a cselekvést pedig alapvetően meghatározza a valóság észlelésének folyamata, „amelyen keresztül kiválasztjuk, rendszerezzük és értelmezzük a környezetböl érkezö információkat, hogy a világról érthetö képet alkossunk" (Kotler \& Keller, 2016, p. 192). Ebben a korlátozott döntési helyzetben egyre nagyobb az impulzusvásárlások szerepe, mely erős emocionális érintettséget feltételez, ahol az inger és a reakció kapcsolata kevésbé tudatos. Mivel ezek az ingerek nagyon sokfélék lehetnek, így nehéz pontosan definiálni, hogy mi milyen hatást fog kiváltani. És gyakran a vásárlók sem tudják szavakba önteni. Ezért lehet kulcsfontosságú a tudatalatti reakciók mérése (Törőcsik, 2011).

Az érintett eszközökhöz képest a szemkamera az agyi aktivitás rögzítése nélkül képes a kognitív folyamatok és a viselkedés vizsgálatára a szemmozgás két típusának (fixációk és szakkádok, melyekre a későbbiekben részletesebben is kitérünk) detektálásával, így egyszerübb és költséghatékonyabb alternatívát nyújtva a marketingkutatások számára.

A neuromarketing-vizsgálatok egyik sajátossága, hogy kvalitatív és kvantitatív eljárások közé is besorolják az irodalomban. Ennek oka leginkább abban áll, hogy a résztvevők száma inkább a kvalitatív mintanagyságok méretéhez igazodik, miközben a mérési pontokból származó adatok mennyisége lehetővé teszi a kvantitatív elemzéseket. Az ezen a területen alkalmazott és a fent áttekintett módszerek jellemzően a tudatos megítélést és a tudatalatti (az agyban lezajló) reakciókat is érintik, így komplex képet szolgáltatva a fogyasztói viselkedések elemeiröl. Míg a kvalitatív módszereket hagyományosan a fókuszcsoportos vitával vagy a mélyinterjúval párosítják, de bármilyen módszerről is legyen szó, a lényege a résztvevők érzéseinek, percepcióinak vagy döntéshozatali mechanizmusainak mélyebb megértése, így jellemzően feltáró jellegü eredményeket várunk tőle. Ehhez képest a kvantitatív megoldások számszerüsíthető és általánosítható adatokat biztosítanak, amit jellemzően egy adott alapsokaságot reprezentáló nagymintás vizsgálat lebonyolításán keresztül érnek el. Ebben az esetben a miértek megértésére nincs lehetőség, hiszen a válaszadók főként zárt kérdésekben mondják el a véleményüket. Természetesen mindkét megoldásnak megvannak az előnyei, de egyértelmüen tapasztalhatók a korlátjaik is. Bár a kvalitatív megoldások segítséget nyújtanak a piaci szereplők viselkedésének és gondolkodásának mélyebb megértésében (Bercea, 2013), Horváth és Mitev (2015) a módszertan leggyakoribb kritikájaként kiemelik, hogy az eredmények a legtöbb esetben nem számszerüsíthetők, így kevésbé tekinthetők kézzelfoghatónak és tudományosnak. Ezen kívül a kvalitatív módszerek gyengeségeként írják le azt is, hogy a kutatási folyamatok nem standardizálhatók, így sok múlik az előkészítési munkálatokon. Ehhez 
képest a kvantitatív módszerek (mint például a kérdőív) eredményei többnyire általánosíthatók, viszont hiányoznak belölük azok az egyéni preferenciákat magyarázó háttér-információk, melyek segítséget nyújtanak a kutatók számára a válaszok mögött meghúzódó motivációk megértéséhez. Ráadásul a direkt módon feltett kérdések a válaszadókat gyakran olyan kényszerü választási helyzetbe hozzák, mely nem tükrözi megfelelően a valóságot, amire persze válaszként felmerül az is, hogy a másik oldalon álló kvalitatív megoldások viszont túlságosan nagy teret adnak az egyéni véleményeknek, aminek hatására a kutatás könnyedén elveszítheti a fókuszát (Bercea, 2013). Éppen ezért gyakran felmerülő kérdéskör e módszertanok kompatibilitásának kérdése, vagyis hogy kiegészítve történő alkalmazásuk vezet a legjobb eredményre (Horváth \& Mitev, 2015), melyre globálisan a kutatások nagyjából felében van példa egy 2018-as elemzés szerint (GRIT Report, 2018).

A neuromarketing-vizsgálatok a legtöbb esetben kísérleten alapulnak, de egyre gyakrabban összekapcsolódnak más, hagyományos kvantitatív és kvalitatív marketingkutatásokkal is.

A különböző módszertani irány közös aspektusát abban látjuk, hogy a neuromarketing-kutatások által nyújtott adatok egyszerre szolgáltatnak összetett képet adó, kvalitatív jellegü információkat a tudatos válaszok alapján, ugyanakkor ezt kiegészítve a fiziológiai folyamatok detektálása révén gyűjtött információk számszerüsíthetö, statisztikai eredményeket is biztosítanak a tudattalan reakciókról. Éppen ezért a kutatás célja ugyanúgy lehet feltáró (ahogyan a kvalitatív módszereké), ahogyan leíró (mint a kvantitatív technikáké) is. Abból a szempontból mindenképpen többet nyújt ez az irány, hogy lehetővé teszi a célcsoportok viselkedésével kapcsolatos adatgyüjtést valós kontextusban, ha például a szemkamerával végzett in-store kutatásokra gondolunk (Bercea, 2013) (1. táblázat).

1. táblázat

A neuromarketing-módszerek kvalitatív és kvantitatív aspektusai

\begin{tabular}{l|l}
\multicolumn{1}{c|}{ kvantitatív } & \multicolumn{1}{c}{ kvalitatív } \\
\hline $\begin{array}{l}\text { A mérési pontokból szár- } \\
\text { mazó nagy mennyiségü adat } \\
\text { statisztikai eredményeket } \\
\text { biztosít. }\end{array}$ & Kis mintaszám (30-40 fö). \\
$\begin{array}{l}\text { A résztvevők tudatos vélemé- } \\
\text { nyét is méri interjús/kérdöí- } \\
\text { ves megkérdezés keretében. }\end{array}$ \\
$\begin{array}{l}\text { hatósággal írja le a résztvevők } \\
\text { tudattalan reakcióit a vizsgált } \\
\text { ingeranyagokkal kapesolat- } \\
\text { ban. }\end{array}$ & $\begin{array}{l}\text { Feltáró jellegü, kiegészítő } \\
\text { információt biztosít a tudat- } \\
\text { talan reakciók eredményeinek } \\
\text { értelmezéséhez }\end{array}$
\end{tabular}

Forrás: saját szerkesztés

\section{Számolni kell a korlátokkal is}

Bár szükségszerü a marketingkutatás folyamatos változása, de az is látszik, hogy a neuromarketing sem tudja teljesen kiváltani a hagyományos kutatási eszközöket. Egyrészt a gazdasági válság hatására átalakult a kutatási iparág, melyben elsődleges szempont a költséghatékonyság (Szücs, 2016), ami azt is jelenti, hogy a költségesnek mondható műszeres kutatási eszközök nehezen tudnak elterjedni a marketingkutatásban. Ezen kívül egy neuromarketing-projekt lebonyolítása interdiszciplináris ismereteket (marketing, pszichológia, szociológia, élettudományok) követel meg a kutatótól, ami sok esetben korlátozottan van jelen egy kutatócégnél (Huszár \& Pap, 2016).

Az eredmények szempontjából kétségtelenül a neuromarketing legnagyobb elönye az az új típusú látásmód, ami a tudatalatti reakciókra koncentrálva kiszüri a válaszadói torzításokat (fóként megfelelő mintaelemszám használatával), de teljesen mégsem képes kiváltani a hagyományos, megkérdezésen alapuló eszközöket, a müszeres technológiák által szolgáltatott eredmények ugyanis sok esetben bonyolultak, értelmezésük a már említett interdiszciplináris ismereteket igénylik, ami persze nem garancia arra, hogy pontosan megértjük a fogyasztók viselkedése mögött húzódó motivációkat, drive-okat. Éppen ezért fontos, hogy ezek a kutatások kiegészüljenek a tudatos megítélésre fókuszáló megkérdezéssel is.

\section{A műszeres megfigyelések fejlődése}

A kutatási gyakorlat során egyre nagyobb népszerüségnek örvendenek a megfigyelésen alapuló módszerek. Simon (2016) is azt hangsúlyozza tanulmányában, hogy a fogyasztói magatartás változása és a technológiai fejlődések kutatás-módszertani hangsúlyeltolódásokat eredményeztek, melynek során egyre nagyobb hangsúlyt kapnak a megfigyeléses és kísérleti kutatások.

Nógrádi-Szabó (2017) etnográfiai kutatásokkal kapcsolatos elemzésében arra hívja fel a figyelmet, hogy az üzleti piackutatásokban végzett megfigyeléses kutatások ma már jelentősen eltérnek az akadémiai gyakorlattól. Míg ez utóbbit a naiv, mindenre kíváncsi megközelítésmód, rugalmasság és a kutatói érdeklődés szabadsága jellemzi, addig a piackutatások praktikus szempontokat vesznek figyelembe és gyakran nincs lehetőség a kutatás tárgyától való eltérésre, így azok sokkal inkább célorientáltan zajlanak. A megfigyeléses módszerek közül az etnográfiai kutatásokat vizsgálva azt találta, hogy a legmarkánsabb különbségeket a kutatás céljában és a kutató szerepében észlelhetjük. Míg az akadémiai megfigyelések célja a legtöbb esetben valamilyen társadalomtudományi kérdés feltárása, melyben a kutató személyes tapasztalatainak és észrevételeinek nagy szerepe van, hiszen az elsődleges cél valamilyen tudás létrehozása, nem kizárólag az adatgyüjtés. Ehhez képest a piacorientált megfigyelések funkciója valamilyen tanácsadási szerep betöltése a marketingfolyamatok (Nógrádi-Szabó, 2017), vagy vezetői döntések előkészítésének támogatására (Neulinger, 2016). Ebben az esetben a kutató szerepe egyértelmüen aktívabb, hiszen a viselkedés megfigyelését minden esetben egy direkt kérdezés egészít ki (Nógrádi-Szabó, 2017). A neuromarketing-vizsgálatok esetében is elmondható, hogy a te- 
repmunkát végző kutató egy objektív megfigyelő, aki nem vesz részt és nem befolyásolja a résztvevőket. Ez azért is fontos, mert míg a kvalitatív módszerek gyakran járnak torzításokkal (például szenzitív kérdések vizsgálata esetén), addig azok a módszerek, melyek explicit módon nem tesznek fel kérdéseket a résztvevők számára, hatékonyabbak a fogyasztói attitüdök vizsgálata során. Ugyanígy alkalmas a döntéshozatali folyamat során kiemelni a viselkedés érzelmi és kognitív aspektusait (Bercea, 2013).

A piac a fogyasztói igények és viselkedés mélyebb megismerésére irányuló egyre intenzívebb igénye a kutatási technikák alkalmazkodását és gyors ütemü fejlődését eredményezte. A fogyasztókkal kapcsolatos valós és részletes információk gyűjtésének egyik leginkább kézenfekvő eszközének tekinthetők a megfigyeléses módszerek, melyek elterjedését a technológiai fejlődés elsősorban az online elérhető megoldásokkal támogatja. Jó példa erre az etnográfiai kutatás és az online közösségek kapcsolódásából létrejött netnográfia módszere. A valós környezetben, vagy laboratóriumi körülmények között megvalósuló online megfigyelések könnyebben elérhető megoldásokat biztosítanak a kutatók számára (Simon, 2016), amely egyrészről egyszerűséggel járó fejlődésként élhető meg, másrészt feszültséget okoz a marketingpiac résztvevői között, hiszen a megbízói oldalon megvalósítható projektek kutató ügynökség bevonása nélkül képesek elérni a fogyasztókat, mely folyamat serkenti a kutatási szolgáltatások fejlődését és specializálódását (Szűcs, 2014).

A hagyományos megfigyeléses módszerek online megvalósításán túl olyan technológiai újítások és interdiszciplináris fejlesztések indultak el, melyek a müszeres mérések népszerüségét eredményezték a piackutatásokban. A gyors technológiai fejlődés lehetővé teszi a kutatók számára, hogy egyre fejlettebb eszközöket használjanak a pszicho-fiziológiai mérések elvégzéséhez. Ezek az eszközök nem csupán az adatok statisztikai elemzésében, de az eredmények vizuális megjelenítésében is segítik öket. A müszeres technikák által szolgáltatott információkban egyértelmüen érzékelhetjük a kiegészítő jelleget, hiszen a tradicionális technikák határait átlépve a tudatalatti vizsgálata egészen mély információkat biztosít akár már a hagyományosan megszokott mintaszám töredékével (Bercea, 2013).

\section{A szemkamerás mérések alapjai}

$$
\begin{aligned}
& \text { "Vannak esetek, amikor a szemek hangosabban } \\
& \text { beszélnek, mint a szavak vagy akár a tettek." (Feng, } \\
& \text { 2011, p. 1) }
\end{aligned}
$$

Bár új típusú eszközként tekintünk leggyakrabban a szemkamerára, mégis komoly múltra tekint vissza. Ez a XIX. század vége óta kutatási és marketingcélokra használt módszer (Lahey \& Oxley, 2016) lehetővé teszi a viselkedés és a kognitív reakciók mérését az agyi aktivitás rögzítése nélkül. Az eszköz jól használható a döntési folyamatok modellezésére és értelmezésére (Franco-Watkins \& Johnson, 2011). A technika iránti alapvető igényt az a folyamat indokolta, amit a figyelem szelektivitásának nevezünk, vagyis hogy az egyén korlátozottan képes az őt körülvevő környezet elemeinek érzékelésére és feldolgozására (Constantinescu, 2016). „A szemkamera által lehetővé válik a figyelem fókuszának és a viselkedés típusainak mérése" (Bercea, 2013, p. 4). Az eszköz képes rögzíteni, hogy mit (melyik terméket, kommunikációs üzenetet stb.) néznek a résztvevők, milyen sorrendben és milyen hosszú ideig teszik ezt. A marketingkutatásokban kevésbé használt funkciója, de a módszer alkalmas érzelmekkel kapcsolatos biometrikus reakciók (a pupillák tágulásának és szükülésének rögzítésével) és mentális erőfeszítések (olyan gyors szemmozgások mérésével, amit szakkádoknak hívunk) vizsgálatára is (Lahey \& Oxley, 2016). A piacon elérhető szemkamerás eszközök többsége a pupilla-központú szaruhártya-tükröződés (pupil centre corneal reflection, PCCR) elve alapján rögzítik a szemmozgást (Gere, 2015). Ezt követően speciális elemző szoftver segítségével az eredmények látványosan ábrázolhatók olyan vizuális megoldásokkal, mint

- a hötérkép (heatmap), ami a megtekintések sürüségéről és az érdeklődés intenzitásáról szolgáltat információt különböző színek segítségével, vagy

- a tekintetkövetési térkép (gaze path), ami pedig a tipikus útvonalakat rajzolja fel, ahogyan a résztvevők megtekintették az adott ingeranyagot.

A vizuális kimenetek nagy előnye, hogy képként, vagy akár videóként is szemléltethetők, így kiemelhető a viselkedés egy fontos momentuma vagy különbsége, de akár egy egész folyamat is vizsgálható a segítségével.

A tekintet követésének detektálása révén a tudatalatti reakciók vizsgálatával ez a technika pontosabb információkat szolgáltat, mint egy megkérdezésen alapuló módszer, amely a válaszadó emlékezetére, benyomásaira hagyatkozik, amennyiben a kutatás fókuszában kommunikációfejlesztés, koncepcióteszt, logó- vagy csomagolásdizájn, online usability-teszt, vagy valamilyen in-store marketingkérdés áll (O’Conell, 2011).

A módszer kiindulópontja az a biológiai jelenség, hogy az ember folyamatosan mozgatja a szemét, mivel a retinának csak egy kis területe ad nagy felbontású képet. A szemmozgás számos típusát különbözteti meg a szakirodalom, melyek közül némelyeknek a látott kép stabilitásának fenntartásában van szerepük, mások viszont új információkat gyüjtenek.

Biológiai szempontból ismerünk szakkádikus szemmozgást, ami az új vizuális információk megszerzésének elsődleges eszköze azáltal, hogy gyors mozgással a tekintetet egyik helyről a másikra helyezi át (Laubrock, Engbert, Rolfs, \& Kliegl, 2007). Két szakkád között a tekintet „egy helyben áll” lehetővé téve a vizuális érzékelést, amit már fixációnak nevezünk. A kutatások során a fixációk sürüségéből és időtartamából következtethetünk a különböző információ észlelésére és feldolgozására. A piacon elérhető legtöbb szemkamera müködése a szakkádok és fixációk rögzítésén alapul (Feng, 2011).

Míg a szakkádok mindössze 30-80 milliszekundum hosszúságúak, addig a fixációk legalább 200-300 ms ideig tartanak (Holmqvist, 2011). Ennyi idő egyszerủ képek, 
vagy rövid, jól ismert szavak (pl. akció) észlelésére elegendő, komplexebb információk, új szavak feldolgozására már minimum 600-800 ms idő szükséges. A szemkamerák jellemzően több kamerával dolgoznak, melyek rögzítik egyrészt a szem mozgását, másrészt az alany környezetét. A legtöbb eszköz infravörös, vagy közel infravörös fényt használ a pupilla és az írisz közötti kontraszt növelésére a követés megkönnyítése érdekében. A tekintet helyzete és a valóság közötti kapcsolat feltérképezése érdekében a mérésnek minden esetben részét képezi egy kalibráció (Feng, 2011), mely során a résztvevő elé vetített pontok követése segítségével kerül összehangolásra az eszköz az alany szemmozgásával annak érdekében, hogy a tárgykamerával felvett kép és a szemkamera által rögzített jelek egységes eredményt adjanak.

Az eszköz kialakítását tekintve a szemkamerák két típusát különböztetjük meg, így a kutatás tárgyához illeszkedően viselhetö, vagy rögzített eszközzel dolgoznak a szakemberek. A mobil szemkamerát jellemzően szemüvegként hordják a résztvevők a kutatás során, melyben két típusú kamera helyezkedik el, a szemkamera a pupilla helyzetét rögzíti, a tárgykamera pedig a környezetet, amit a résztvevő láthat. Ehhez képest az úgynevezett stabil szemkamera - melyet elsősorban weboldal, vagy kommunikáció tesztelés során használnak - egy monitorhoz rögzítve működik. A felépítésében tapasztalható fő különbség abban van, hogy a képet, amit a résztvevő lát, automatikusan rögzíti, így tárgykamerára nincs szükség, az infravörös fénnyel detektált jelek ezen a képen jelennek majd meg. Az eszközök típusának végül az elemzés során is nagy szerepe lesz. Míg a stabil - képernyőre rögzített - szemkamera adatai automatikusan elemezhetök az erre a célra fejlesztett szoftver segítségével, addig a mobil szemkamera felvételeit manuális adatrögzítés révén dolgozzák fel. Erre megoldásként ma már léteznek különböző jelölök, melyek például egy polc képét képesek rögzíteni az automatikus elemzéshez, azonban korlátozottan használhatók például egy in-store kutatásban, így inkább kísérletek során alkalmazható.

Bercea (2012) tanulmánya alapján készített 2. táblázat szakirodalmi áttekintést ad az eszköz által mért mutatókról, az alkalmazási területekröl, illetve előnyeiről és korlátairól.

A szemmozgás-vizsgálatok és -elemzések elsődleges célja olyan insight-ok összegyüjtése, melyek által megismerhetők a figyelemmel kapcsolatos viselkedések. Az eszköz relatíve kis minta bevonásával megbízhatóan megmutatja, hogy hova néznek a résztvevők, milyen sorrendben és mennyi ideig (O'Connell, Walden, \& Pohlmann, 2011). A vizsgálat során gyüjtött adatok elemzése során számos statisztikai mutatószám figyelembevételére van lehetőség, úgymint

- teljesítmény mutatók:

- hatékonyság: az adott feladat elvégzésére szánt idő,

- eredményesség: a hibás mérések száma,

- folyamat mutatók:

- fixációk száma, ami a ránézések arányát mutatja meg az ingeranyag feldolgozása során,

- fixációk időtartama, ami a kognitív funkciók kor- relációját mutatja (hosszabb ránézések növekvő kognitív folyamatokat jeleznek), ebben az esetben mérhető az ingeranyagra történő első, vagy a teljes ránézés hossza,

- figyelemváltozás, ami a vizuális figyelem eloszlásának mutatója,

- ránézési útvonal hasonlósága, ami különböző résztvevők szemmozgását hasonlítja össze (Duchowski, 2007).

A folyamatmutatók értelmezhetők a teljes ingeranyag egészére nézve, de akár annak elemeit illetően is. Ez utóbbit érdeklődési területek (AOI - Areas of Interest) kijelölésével mérhető.

2. táblázat

Szemkamerás módszer mutatói, alkalmazási területei és jellemzői

\begin{tabular}{|c|c|}
\hline Mit I & Hol használják? \\
\hline $\begin{array}{l}\text { - Vizuális fixáció } \\
\text { - Keresés } \\
\text { - Mintázatok a szem mozgá- } \\
\text { sában } \\
\text { - Térbeli felbontás } \\
\text { - Figyelemfelkeltés, izgalo- } \\
\text { mérzet } \\
\text { - Pupillaméret (tágulása és } \\
\text { szúküllése) }\end{array}$ & $\begin{array}{l}\text { - Weboldalak és felhasználói } \\
\text { felületek tesztelése (usability } \\
\text { tesztek) } \\
\text { - In-store vizsgálat } \\
\text { • Csomagolásvizsgálat } \\
\text { - Hirdetések, kommunikációs } \\
\text { anyagok vizsgálata (videó, } \\
\text { print, online) } \\
\text { - Koncepciótesztek } \\
\text { - Fogyasztói információszürés } \\
\text { vizsgálata } \\
\text { - Észlelési útvonalak, } \\
\text { hierarchiák felállítása (mely } \\
\text { információk rögzülnek, keltik } \\
\text { fel a figyelmet elöször) } \\
\text { - Polcképek és termék-kihelye- } \\
\text { zések tesztelése }\end{array}$ \\
\hline Előnyei & $\mathbf{R}$ \\
\hline $\begin{array}{l}\text { - A pupillák tágulásának és a } \\
\text { pislogás sebességének vál- } \\
\text { tozása pontos információt } \\
\text { tud nyújtani a résztvevők } \\
\text { involváltságáról és izgatott- } \\
\text { ságáról. } \\
\text { • Hordozható - a szemka- } \\
\text { merás mérések az eszköz } \\
\text { mobilitásának köszönhetően } \\
\text { bárhol elvégezhetők } \\
\text { - Képes a térbeli figyelem } \\
\text { detektálására }\end{array}$ & $\begin{array}{l}\text { - Költséges módszer - föként a } \\
\text { technikai támogatás (szemka- } \\
\text { mera, megfelelő számítógép, } \\
\text { rögzítő és elemző szoftver) } \\
\text { miatt. } \\
\text { • Megkérdőjelezhető a megbíz- } \\
\text { hatósága } \\
\text { - Az eredmények nagyban füg- } \\
\text { genek az emberi tényezőktől } \\
\text { (pl. a résztvevő szemének } \\
\text { müködésétől). }\end{array}$ \\
\hline
\end{tabular}

\section{A megbízható minta nagysága a marketingkutatásban}

A mintavétel fogalmát elsősorban a kvantitatív kutatásokkal kapcsolják össze, azonban nagy jelentősége van a kvalitatív tanulmányok során is, igaz, kissé más szempontból. Míg a nagymintás elemzések esetében a cél egy adott sokaságra nézve érvényes és megbízható eredmények biztosítása, addig leíró kutatásoknál az adott csoport mélyebb 
és pontosabb megértése a cél (Ghauri \& Grønhaug, 2016). A hagyományos kvantitatív elemzések esetében általánosan elmondható, hogy a megbízhatóság növelhető a mintaszám növelésével. A mintaszám meghatározása és a mintavételi megoldás kiválasztásának jelentősége rendkívül nagy, hiszen adott alapsokaságból vett különböző minták eltérő eredményeket produkálhatnak attól függően, hogy mely mintából származnak, amit véletlen hibának nevezünk (Bárczi, Lőkösi, \& Gál, 2017).

A matematikában a valószínüség-számítás szolgáltat megfelelő megoldást annak becslésére, hogy a felvett mintastatisztikák mennyire szorosan tömörülnek a valódi érték körül, amit mintavételi hibabecslésnek nevezünk. Ennek három fontos tényezőjét jelenti egyrészt a paraméter, ami az adott populáció egy változóba tömörített összefoglaló tulajdonságait jelenti, a mintanagyság és a standard hiba. Az utóbbi azt mutatja meg, hogy a mintabecslések milyen mértékben szóródnak a populációs paraméter körül. Azt már tudjuk, hogy a mintanagyság és a standard hiba szoros kapcsolatban állnak egymással, hiszen nagyobb elemszám esetén a mintabecslések szóródása kisebb (Babbie, 2001). A megbízhatósági intervallum meghatározása a pontbecslés, a standard hiba és a becslőfüggvény eloszlástípusának ismeretében történik, melyekből kiszámítható a becslés megbízhatósága (milyen valószínűséggel tartalmazza a becsülni kívánt jellemzőt) és pontossága (mekkora a hibahatár) (Pintér \& Rappai, 2007).

A szemkamerás kutatásokra főként a nem valószínűségi mintavétel jellemző, melynek kiindulópontja a célcsoport legfontosabb jellemzőinek ismerete, mely szüröként szolgál a rekrutáció során. Ez azt is jelenti, hogy jellemzően nem törekszik teljes sokaságra nézve általánosítható eredmények elérésére, sokkal inkább egy adott célcsoportra vonatkozóan megbízható információkra.

A neuromarketing-tanulmányokban alkalmazott mintaméretek meghatározása folyamatosan tudományos vitának ad felületet, hiszen a hagyományos módszerek támogatóinak álláspontja szerint a kis mintán végzett vizsgálatok nem alkalmasak érvényes következtetések levonására. Button et al. (2013) statisztikaközpontú megközelítése szerint a kis mintaszám okozta alacsony statisztikai erő negatív hatással van az adatok megbízhatóságára, míg Bacchetti (2013) ezzel kapcsolatban kifejti, hogy a valódi problémát a statisztikai mutatók helyes értelmezése okozza. Ehhez képest Hensel (2017) Genco, Pohlmann és Steidl 2013-ban készült neuromarketing-tanulmányára hivatkozva azzal érvel, hogy az agyi aktivitások alacsonyszintü véletlenszerüsége miatt elegendő kisebb minta is, amit négy évvel korábban Sands (2009) az EEG-módszertant vizsgálva is alátámasztotta. A hagyományos és neuromarketing-módszertani irányvonal mintavételi megoldásai között a fő különbséget az jelenti, hogy az utóbbihoz tartozó kutatások nem igényelnek teljes populációra nézve reprezentatív mintát, hiszen a célcsoport pontosan definiálásra kerül a kutatás célja alapján meghatározott demográfiai vagy magatartásbeli szempontok szerint (Hensel, Iorga, Wolter, \& Znanewitz, 2017). Kvantitatív szempontból a kognitív folyamatok mérései közé tarto- zik minden olyan reakció vizsgálata, mely a résztvevők fejében történik (figyelem, felidézés, memória stb.). A kis mintanagyság ellenére az eredmények általánosíthatók az adott célcsoportra nézve, hiszen egy résztvevőtől nagy mennyiségű elemezhető adat gyüjthető, ezen kívül - ahogyan a neuromarketing-vizsgálatok módszertani elhelyezése során is láttuk - az emberek agymechanizmusai hasonlók, így összességében a mennyiségi vizsgálatokhoz közelebb is áll (Bercea, 2013). Mindez alátámasztja azt a megállapítást is, mely az EEG, mint neuromarketing-eszköz megfelelő mintanagyságát vizsgálva azt találta, hogy 30-40 fös minta esetében (célcsoportonként) az eredmények megbízhatósága már 95\% is lehet (Sands, 2009). A minta mérete nagyban függ a kiválasztott technikáktól és eszközöktől, így például az agyi funkciók mérése kisebb elemszámot igényel, mint egy arcolvasó müszer (Hensel et al., 2017). Az fMRI-vizsgálatok esetében az alkalmazott ökölszabály például 15 résztvevőben határozza meg a felvett minta minimumát a megfelelö érvényesség elérése és az egyéni neuroanatómiai különbségek kiküszöbölése érdekében (Reimann, Schilke, Weber, Neuhaus, \& Zaichkowsky, 2011).

Mindemellett fontos azt is figyelembe venni, hogy egy nem véletlenszerüen felvett, elfogult populációból vett nagy minta - mely nem reprezentálja megfelelöen az alapsokaságot - éppoly értéktelen lehet, mint egy túl kisméretü minta (Hensel et al., 2017).

Összességében tehát azt kell elsőként megfontolni, hogy a kutatási kérdések megválaszolásához milyen típusú adatra van szükség és pontosan definiálni kell az elemzési egységet (Ghauri \& Grønhaug, 2016). Kvalitatív szempontból az elemzés tárgyát a részt vevő személyek adják, melyek elemszáma valóban alacsony, azonban a szem mozgásának detektálásakor 30 ember részvételével rendkívül nagy mennyiségü más típusú adat születik, melyek már alkalmasak a statisztikai megközelítésü elemzések elvégzésére.

Ezen kívül a szemkamerás vizsgálatok esetében a mintaszám meghatározása során érdemes figyelembe venni a sikertelen, illetve hiányos adatállományokat, melyek elsősorban az egyéni szem biológiájából fakadnak. Nielsen és Pernice (2009) javaslata alapján, mivel egy megbízható hőtérkép elkészítéséhez 30 résztvevő bevonása szükséges, ezért - számolva azzal, hogy a résztvevők nagyjából 23\%a a kalibráció vagy az eszköz pontatlansága miatt nem megfelelő minőségű vagy hiányos adatot generálhat - a kutatás során 39 főt érdemes lemérni. A szerzők (Nielsen \& Pernice, 2009) felhívják a figyelmet arra is, hogy olyan kvalitatív eye tracking vizsgálat esetén, mint egy usability teszt persze elegendő 6 fő vizsgálata is, ami leíró jellegü eredményeket biztosít, melyből a legjellemzőbb hibák már detektálhatók.

A kutatópáros egy egyszerü példán keresztül illusztrálta az általuk javasolt mintaszám helyességének bizonyítását. Egy weboldalvizsgálat során 60 fö vett részt a szemkamerás kutatásukban. Ebből a 60 főből először hat 10 fös, majd három 20 fös, végül két 30 fös mintát vettek és készítették el adott időegységeket ábrázoló hőtérképeiket. A kísérlet konklúziója minden vizsgált weboldal 
esetében az volt, hogy 10-20 fös mintaszám mellett még megbízhatatlanok az eredmények, azonban 30 fó esetén stabilizálódnak az adatok, nem mutatnak jelentős eltérést a mintavételtől függően.

Determinációs együtthatót használva $\left(\mathrm{R}^{2}\right)$ Nielsen és Pernice (2009) statisztikailag is alátámasztotta az állítását és azt találták, hogy míg tíz résztvevő bevonásával a szemkamerás eredmények megbízhatósága $47 \%$, addig 30 fó részvétele mellett ez a szám már $85 \%$. Ez azt jelenti, hogy ekkora mintaszám esetén mindössze $15 \%$ az esélye annak, hogy egy másik 30 fős mintán mérve az eredmények azonossága a véletlen müve (1. ábra).

A determinációs együttható két skálán mért változó kapcsolatának erősségét és a regressziós függvény illeszkedését mutatja 0-1 értékek között, ahol a 0 érték azt jelenti, hogy nincs kapcsolat a két változó között, míg a maximális értékét determinisztikus kapcsolat esetén veszi fel.

1. ábra

\section{A mintaszámok megbízhatósága szemkamerás módszertan esetében}

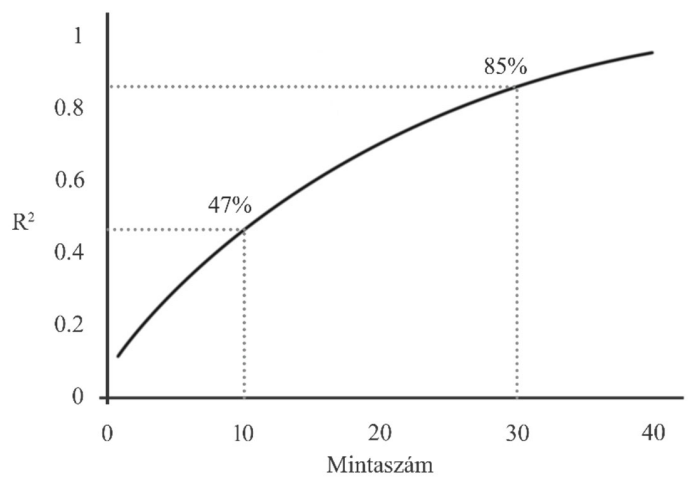

Forrás: Nielsen \& Pernice (2009, p. 51)

Mindezek mellett természetesen nem egyszerü feladat a szemkamerás vizsgálatok megfelelő mintaszámának meghatározása, hiszen nem minden esetben ideális 30 fös minta vétele, a kutatónak számos szempont figyelembevételére van szüksége ahhoz, hogy ezt a döntést meg tudja hozni. Elsősorban nem mindegy, hogy mi a kutatás célja (Bojko \& Adamczyk, 2010). Ahogyan már láttuk kvalitatív jellegü UX-vizsgálatnál akár már 6 fő is megfelelö, míg ha statisztikai eredményekre is szükségünk van, akkor legalább 30 résztvevőre lesz szükségünk. A mintaszámot, azonban meghatározza a vizsgált ingeranyagok száma is, hiszen egy résztvevő korlátozott információ feldolgozására képes, így nagy mennyiségü stimulus vizsgálata esetén ezek megosztására kényszerülünk, ami nagyobb mintát eredményez annak érdekében, hogy minden ingeranyag esetében megfelelő mennyiségű információval rendelkezzünk. Ugyanígy befolyásoló tényező a célcsoportok definiálása is, hiszen ez a 30 fö egyetlen (cél)csoportot fed le.

A 2010-es évek elején bontakozott ki a tudományos vita a neuromarketing-kutatásokban alkalmazott minták méretének helyességével kapcsolatban. Az egyik oldal azt állította, hogy alacsony mintaszám mellett kis valószínüséggel mondhatjuk csak azt, hogy statisztikailag szignifikáns eredmény (kis mintaszám, vagy alacsony hatás mellett) valóban a valóságot tükrözi. A neuromarketingben használt korlátozott mintanagyság következtében az eredmények alacsony megbízhatósággal lesznek reprodukálhatók, ami a kutatások hasznát etikailag is megkérdőjelezheti. Tanulmányukban három fö problémát fogalmaznak meg a kutatók, amelyek hozzájárulnak az alacsony megbízhatóságú eredmények létrehozásához: a valódi hatások kis valószínűsége, alacsony előrejelezhetőségi értéke és nagyságának túlzó becslése. Ezért az alacsony mintaszámot akkor tartják csak elfogadhatónak, ha a vizsgált hatás valóban olyan erős, hogy mérhető legyen kevés számosságú résztvevő bevonásával, ha a hatást már nagy elemszám mellett bizonyították (Button et al., 2013). Egyes elemzések azt mutatják, hogy e vizsgálatok megbízhatósága legfeljebb 30\%. Ezzel szemben a másik oldal álláspontja szerint nem a mintanagyság a kutatások fő gyengesége, hanem az eredmények értelmezése, hiszen óriási különbség van 0,049 és 0,0001 szignifikanciaérték információtartalma között, ami mellett érdemes figyelembe venni a becsült hatásokat és konfidencia intervallumokat is (Bacchetti, 2013).

Ennek ellenére a neuromarketing-módszerek népszerüsége egyre növekszik, így van ez a szemkamerás vizsgálatokkal is, mely egyre nagyobb teret nyer a gazdasági döntéshozatal vizsgálatában. Az olyan bonyolult és költséges eljárásokkal szemben, mint az fMRI, az eye-tracking egyszerü mérésekkel és eszközökkel lehetővé teszi a valós tudatalatti reakciók vizsgálatát (Król \& Król, 2017).

\section{Konklúziók}

A szemkamerás módszertannal foglalkozó szakirodalmak feldolgozása során nagyon eltérő nézőpontokkal találkoztunk a mintaszám meghatározását illetően. A legtöbb kutatás elfogadja azt az általánosnak mondható irányvonalat, mely szerint a neuromarketing-kutatások eredményei 30 fö vizsgálatával megbízható eredményeket szolgáltatnak homogén célcsoport esetén. Ennek tudományos megalapozottságát az idegtudományok azon megállapítása adja, miszerint az emberek fiziológiai folyamatai hasonlók, így kis mintaszám mellett is általánosíthatók. Ezt pedig Nielsen és Pernice (2009) kísérlete is látványosan alátámasztja.

A hagyományos kutatási módszerek és a matematikai szakemberek statisztikai érvényességet érintő kétségei mellett némi szkepticizmusra adhat azonban okot a piaci gyakorlatban tapasztalható anyagi nyomás is, ami a marketingkutatókat és szakmai intézményeket a mintaszámok csökkentésére kényszeríti.

A neuromarketing-kutatások piaci megvalósítását tekintve nehéz vázolni egy standard folyamatot, hiszen minden projekt egyedi. Az új technológiák komoly időbefektetést jelentenek, hiszen a kutatás tervezésétől kezdve a terepmunkán keresztül az eredmények értelmezéséig speciális eljárásról beszélhetünk (Berčík, 2016). A müszeres megfigyelések jelenleg gyakran kiegészítő kutatásként jelennek meg a projektekben, aminek köszönhetően a minta megbízhatósága másodlagos szerepet játszik a 
tervezésben. Berčík (2016) összefoglalójából ezen kívül az is látszik, hogy a mintaszám meghatározására számos gyakorlat létezik, melyet az alábbi táblázat szemléltet a szakterületen müködő intézmények elérhető kutatásai alapján. Jól látszik, hogy a kutatási minta mérete nemcsak a felhasznált kutatási eszköztől, hanem az érintett kutatási tevékenységet szervező intézménytől is függ. A 3. táblázat az eredeti összeállításból azokat az intézményeket tartalmazza, melyek végeznek szemkamerás vizsgálatokat.

3. táblázat

\section{Standard mintaszámok alakulása a kiválasztott neuromarketing-intézmények körében}

\begin{tabular}{|c|c|c|c|}
\hline Módszer & $\begin{array}{c}\text { Minta- } \\
\text { szám }\end{array}$ & Intézmény & Kutató \\
\hline $\begin{array}{c}\text { EEG, Eye } \\
\text { tracker, IAT, } \\
\text { Facial coding }\end{array}$ & 65 & Ipsos Neurosience & Elissa Moses \\
\hline $\begin{array}{c}\text { fMRI, Eye } \\
\text { tracker }\end{array}$ & $30-40$ & $\begin{array}{c}\text { University of Bonn/ } \\
\text { Life\&Brain GmbH }\end{array}$ & Bernd Weber \\
\hline $\begin{array}{c}\text { Eye tracker, } \\
\text { EEG, Facial } \\
\text { coding, fMRI }\end{array}$ & $40-50$ & $\begin{array}{c}\text { Copenhagen } \\
\text { Business School/ } \\
\text { Neurons Inc. }\end{array}$ & $\begin{array}{c}\text { Thomas } \\
\text { Ramsøy }\end{array}$ \\
\hline $\begin{array}{c}\text { EEG, Eye } \\
\text { tracker, GSR, } \\
\text { EKG, BVP }\end{array}$ & $18-96$ & $\begin{array}{c}\text { Neuromarketing } \\
\text { S.A. de C.V. } \\
\text { (NMKT) }\end{array}$ & Jaime Ro- \\
mano \\
\hline $\begin{array}{c}\text { EEG, Eye } \\
\text { tracker, GSR, }\end{array}$ & $25-40$ & $\begin{array}{c}\text { Neuromarketing } \\
\text { Labs }\end{array}$ & Hirak Parikh \\
\hline $\begin{array}{c}\text { fMRI, Eye } \\
\text { tracker }\end{array}$ & $20-30$ & Neurensics & Martin de \\
\hline $\begin{array}{c}\text { fMRI, EEG, } \\
\text { Eye tracker, } \\
\text { EKG, GSR }\end{array}$ & $12-72$ & $\begin{array}{c}\text { Universite Catho- } \\
\text { lique de Lille/ Brain } \\
\text { Impact }\end{array}$ & Arnaud Petre \\
\hline $\begin{array}{c}\text { EEG, Eye } \\
\text { tracker, Facial } \\
\text { coding }\end{array}$ & $18-60$ & $\begin{array}{c}\text { Slovak University } \\
\text { of Agriculture in } \\
\text { Nitra }\end{array}$ & Jakub Bercik \\
\hline $\begin{array}{c}\text { EEG, Eye } \\
\text { tracker }\end{array}$ & 100 & $\begin{array}{c}\text { Millward Brown } \\
\text { Gahn Page }\end{array}$ & Graham Page \\
\hline
\end{tabular}

Forrás: Berčík (2016, p. 9)

Brečík (2016) gyűjteményében található szakemberek és intézmények által kiadott kutatások és összefoglalók többsége, ahogyan a szakmai anyagok meghatározó része sem tér ki a mintaszám meghatározásának magyarázatára. A szakirodalom és a gyakorlati kutatásokból származó anyagok szükre szabott információkat és véleményeket tartalmaznak a kérdésben.

A rendelkezésre álló elemzések alapján az látszik, hogy az eszköz kiválasztásán túl a mintaszám meghatározása gyakran a kutatásra fordított anyagi lehetőségek tükrében valósul meg (Sánchez, 2015), mely során egyensúlyt kell teremteni a toborzás, az adatgyüjtés és a mintaméret növelésének költségei között (Hensel et al., 2017). Ezért lehetséges például, hogy a Millward Brown akár száz föt is be tud vonni egyes projektekbe, míg az egyetemi keretek között zajló kutatások jellemzően 30-60 fővel zajlanak.

Elissa Moses az IPSOS Neuro and Behavior Science Innovation Center vezetőjének tapasztalatai szerint ez egy rendkívül komplex, sok elemből álló kérdés, de a 30 fős minta részben a költségek alacsonyan tartása miatt optimális. Ha a módszereket nézzük, akkor ennek a szemkamera esetében van leginkább létjogosultsága, hiszen olyan egyszerüen megfigyelhető fiziológiai jelenséget mér, mint a szemmozgás, ha azonban mélyebb, kontextuális információkra vagyunk kíváncsiak, mint a kulturális referenciák, vagy egyéni percepciók, akkor már nagyobb elemszámú megkérdezésre van szükség (Sánczez, 2015).

Ehhez hasonlóan a Millward Brown korábbi elnöke, Gordon Pincott (2015) is úgy látja, hogy a piaci gyakorlatban a költségekre nehezedő nyomás csökkentette leginkább a szemkamerás és más neuromarketing-technikák mintaszámát. Ez pedig a média és kutatási környezet megváltozásával járt, ami új típusú kihívásokat jelentett a kutatók számára, hiszen a minták méretei egyre inkább korlátozzák az elemzések mélységét.

Összességében azt látjuk, hogy a neuromarketing-technikák, ezen belül pedig a szemkamerás módszertan népszerüségének növekedése mindenképpen indokolja egy hiánypótló empirikus elemzés megvalósítását, mely alátámasztja, vagy éppen megcáfolja a jelenlegi gyakorlatot az alkalmazott mintaszámokkal kapcsolatban.

\section{Felhasznált irodalom}

Ariely, D., \& Berns, G. (2010). Neuromarketing: the hope and hype of neuroimaging in business. Nature Reviews Neuroscience, 11(4), 284-292. https://doi.org/10.1038/ nrn2795

Bacchetti, P. (2013). Small sample size is not the real problem. Nature Reviews Neuroscience, 14(8), 585. https://doi.org/10.1038/nrn3475-c3

Bárczi J., Lőkösi K., \& Gál Zs. (2017). A statisztika módszertani lehetőségeinek alkalmazása az üzleti elemzési eljárásokban. Controller Info, 5(3), 18-22. https://doi.org/10.24387/CI.2017.3.4

Bercea, M. D. (2013). Quantitative versus qualitative in neuromarketing research. Letöltve https://mpra. ub.uni-muenchen.de/44134/

Bercea, M. D. (2012). Anatomy of methodologies for measuring consumer behavior in neuromarketing research. In Proceedings of the Lupcon Center for Business Research (LCBR) European Marketing Conference (pp. 1-14). Ebermannstadt, Németország.

Berčík, J. (2016). Consumers Neuroscience as a Modern Consumer Research Tool: Ethical Aspects and Size of the Research Sample. In C. Olexová \& M. Janošková (Eds.), Marketing Management, Trade, Financial and Social Aspects of Business Conference Proceedings of the 4th International Scientific Conference (pp. 6-11). Pozsony: Košice University of Economics.

Bojko, A., \& Adamczyk, K. A. (2010). More than Just Eye Candy Top Ten Misconceptions about Eye Tracking. User Experience, 9(3), 3-8.

Button, K. S., Ioannidis, J. P. A., Mokrysz, C., Nosek, B. A., Flint, J., Robinson, E. S. J., \& Munafò, M. R. (2013). Power failure: why small sample size undermines the reliability of neuroscience. Nature Reviews Neuroscience, 14(5), 365-376. https://doi.org/10.1038/nrn3475 
Constantinescu, M. (2016). New Trends in Marketing Research: Neuromarketing and Eye Tracking. In G. Mazurek \& J. Tkaczyk (Eds.), The impact of the digital world on management and marketing (pp. 111-124). Warsawa: Kozminsky University.

Duchowski, A. (2007). Eye Tracking Methodology: Theory and Practice. London: Springer-Verlag. https:// doi.org/10.1007/978-1-84628-609-4

Feng, G. (2011). Eye Tracking: A Brief Guide for Developmental Researchers. Journal of Cognition \& Development, 12(1), 1-11. https://doi.org/10.1080/1524 8372.2011.547447

Franco-Watkins, A., \& Johnson, J. (2011). Decision moving window: using interactive eye tracking to examine decision processes. Behavior Research Methods, 43(3), 853-863. https://doi.org/10.3758/s13428-011-0083-y

Ghauri, P., \& Grønhaug, K. (2016). Kutatásmódszertan az üzleti tanulmányokban. Budapest: Akadémiai Kiadó. https://doi.org/10.1556/9789630598590

GRIT Report (2018). Letöltve https://issuu.com/ researchshare/docs/grit_q1-q2_2018_final_report

Hensel, D., Iorga, A., Wolter, L., \& Znanewitz, J. (2017). Conducting neuromarketing studies ethicallypractitioner perspectives. Cogent Psychology, 4(1), 1-13. https://doi.org/10.1080/23311908.2017.13208 58

Holmqvist, K., Nyström, M., Andersson, R., Dewhurst, R., Jarodzka, H., \& Van de Weijer, J. (2011). Eye tracking: A comprehensive guide to methods and measures. Oxford: Oxford University Press.

Horváth, D., \& Mitev, A. (2015). Alternatív kvalitatív kutatási kézikönyv. Budapest: Alinea Kiadó.

Hubert, M. (2010). Does neuroeconomics give new impetus to economic and consumer research? Journal of Economic Psychology. Special Issue on Decision Neuroscience, 31(5), 812-817. https://doi.org/10.1016/j. joep.2010.03.009

Huszár, S. \& Pap, K. (2016). Revolutioning marketing research? A critical view on the promising neuromarketing. In Lengyel I. \& Vas Zs. (Eds.), Economics and Management of Global Value Chains (pp. 157-166). Szeged: Szegedi Tudományegyetem.

Kotler, P., \& Keller (2016). Marketingmenedzsment. Budapest: Akadémiai Kiadó. https://doi. org/10.1556/9789630597784

Król, M., \& Król, M. (2017). A novel approach to studying strategic decisions with eye-tracking and machine learning. Judgment \& Decision Making, 12(6), 596609.

Lahey, J. N., \& Oxley, D. (2016). The Power of Eye Tracking in Economics Experiments. American Economic Review, 106(5), 309-313. https://doi.org/10.1257/aer. p20161009

Laubrock, J., Engbert, R., Rolfs, M., \& Kliegl, R. (2007). Microsaccades are an index of covert attention: Commentary on Horowitz, Fine, Fencsik, Yurgenson, Wolfe. Psychological Science, 18(4), 364-366. https:// doi.org/10.1111/j.1467-9280.2007.01904.x
Loken, B. (2006). Consumer Psychology: Categorization, Inferences, Affect, and Persuasion. Annual Review Of Psychology, 57(1), 453-485. https://doi.org/10.1146/ annurev.psych.57.102904.190136

Neulinger Á. (2016). Több-módszertanú és vegyes módszertanú kutatások. Korreferátum Simon Judit „kutatás-módszertani trendek a marketingben” című tanulmányához. Vezetéstudomány, 47(Marketingtudományi Különszám), 63-75.

Nielsen, J., \& Pernice, K. (2009). How to conduct eye tracking studies. Letöltve https://media.nngroup.com/ media/reports/free/How_to_Conduct_Eyetracking_ Studies.pdf

Nógrádi-Szabó, Z. (2017). Hiszem, amit látok, vagy látom, amit hiszek? Etnográfia a kvalitatív piackutatásban a terepmunkától a videofilmig. Vezetéstudomány, 48(12), 61-70. https://doi.org/10.14267/VEZTUD.2017.12.07

O'Connell, B., Walden, S., \& Pohlmann, A. (2011). Marketing and Neuroscience. What Drives Customer Decisions? American Marketing Association, White Paper. Letöltve https://www.hoffmanmarcom. com/ama/white-papers/White $\% 20$ Paper $\% 20$ Neuroscience $\% 20$ what $\% 20$ drives $\% 20$ cust $\% 20$ descisions.pdf

Picott, G. (2015). Tracking at the Crossroads. Letöltve https://www.millwardbrown.com/docs/default-source/ insight-documents/points-of-view/Millward_Brown_ POV_Tracking_at_the_Crossroads.pdf

Pintér J., \& Rappai G. (2007). Statisztika. Pécs: PTE KTK. Reimann, M., Schilke, O., Weber, B., Neuhaus, C., \& Zaichkowsky, J. (2011). Functional Magnetic Resonance Imaging in Consumer Research: A Review and Application. Psychology \& Marketing, 28(6), 608637. https://doi.org/10.1002/mar.20403

Sands, S. F. (2009). Sample Size Analysis for Brainwave Collection (EEG) Methodologies. Letöltve http://www. sandsresearch.com/assets/white-paper.pdf

Sánczes, E. (2015). Neuromarketing, Interview with Elissa Moses (I/III), IPSOS Executive VP of Neuro and Behavior Science Innovation Center. Letöltve http:// lets-neuromarketing.it/neuromarketing-interviewwith-elissa-moses-ipsos-1-3/

Simon, J. (2016). Kutatás-módszertani trendek a marketingben. Vezetéstudomány, 47(4), 54-74.

Simon, H., Hajnal, A., Kindler, J., Kiss, I., \& Csontos, L. (1987). Korlátozott racionalitás: válogatott tanulmányok. Budapest: Közgazdasági és Jogi Könyvkiadó.

Szücs K. (2014). Válaszadási hajlandóságot befolyásoló attitüdök. In Hetesi Erzsébet - Révész B. (szerk.), Marketing megújulás: Marketing Oktatók Klubja 20. Konferenciája, Szeged. Szeged: SZTE GTK.

Szücs, K. (2016). Marketingkutatás 2.0.Vezetéstudomány, 47(4), 67-75.

Törőcsik, M. (2011). Fogyasztói magatartás: insight, trendek, vásárlók. Budapest: Akadémiai Kiadó.

Varga, Á. (2016). Neuromarketing, a marketingkutatás új iránya. Vezetéstudomány, 47(9), 55-63. 